\title{
Continuous Long-Term Observation of Suspended Sediment Transport between Two Pumped-Storage Reservoirs
}

\author{
Michael Müller'; Giovanni De Cesare²; and Anton J. Schleiss ${ }^{3}$
}

\begin{abstract}
Transport of suspended sediment between the two reservoirs of a pumped-storage plant in Switzerland was monitored over an 8-month period. A turbidity probe was installed on the upstream end of the pressure shaft, in which real-time monitoring was ensured by automatic data acquisition and remote control. The suspended sediment concentration in the reservoirs varies considerably over the course of a year, with low particle loads in the winter, when the reservoirs are covered by ice and the catchment area is entirely covered by snow. In late spring, when snowmelt starts, the suspended sediment concentration increases and remains high until summer. The short-term evolution of the suspended sediment concentration was found to be correlated to the pumped-storage sequences, especially when the reservoir levels are low. Higher concentrations during pumping mode were observed for low levels in the lower reservoir, and low levels in the upper reservoir corresponded to higher sediment concentrations in turbine mode. Concentration ratios between pumping and turbine mode between 0.93 and 1.16 were observed. Periods with higher particle load were observed more frequently during pumping mode. Nevertheless, the suspended sediment balance due to pumped-storage operations is equilibrated, which indicates a high degree of correlation between the transported sediment volume and hydropower operation. Connecting the applied monitoring system in an existing plant control and management system would allow the plant operator to detect increased suspended sediment loads in the pressure shaft and to adapt the operation mode to actively manage reservoir sedimentation or to estimate and predict the long-term sediment balance. DOI: 10.1061/ (ASCE)HY.1943-7900.0000866. () 2014 American Society of Civil Engineers.
\end{abstract}

Author keywords: Reservoir sedimentation; Suspended sediment transport; Turbidity measurement; Continuous long-term monitoring; Pumped-storage hydropower plant.

\section{Introduction}

Approximately 56\% of Swiss electricity production comes from hydropower, and the federal government is greatly promoting the use of this renewable energy source. The development of new pumped-storage facilities for grid regulation and peak energy supply has become a crucial task for sustainable power production. Maximum plant efficiency, production reliability, and structural safety are required. Reservoir sedimentation is one of the problems to be examined because it causes storage losses and clogging of intakes and outlets (Fan and Morris 1992; Hartmann 2007; Jenzer Althaus et al. 2005; Knoblauch et al. 2005).

The main sedimentation processes that affect large Alpine storage reservoirs are turbidity currents. When a sediment-laden river enters a reservoir, it plunges and follows, depending on the density difference, the thalweg to the deepest area, which is normally close

${ }^{1}$ Doctor of Science, IUB Engineering Ltd., Belpstrasse 48, CH-3000 Bern 14, Switzerland; formerly, Laboratory of Hydraulic Constructions, Ecole Polytechnique Fédérale de Lausanne (LCH-EPFL) (corresponding author). E-mail: michael.mueller@iub-ag.ch

${ }^{2}$ Doctor of Science, Laboratory of Hydraulic Constructions, Ecole Polytechnique Fédérale de Lausanne (LCH-EPFL), Station 18, CH-1015 Lausanne, Switzerland. E-mail: giovanni.decesare@epfl.ch

${ }^{3}$ Professor, Doctor of Science, Laboratory of Hydraulic Constructions, Ecole Polytechnique Fédérale de Lausanne (LCH-EPFL), Station 18, CH-1015 Lausanne, Switzerland. E-mail: anton.schleiss@epfl.ch

Note. This manuscript was submitted on December 12, 2012; approved on January 3, 2014; published online on February 18, 2014. Discussion period open until July 18, 2014; separate discussions must be submitted for individual papers. This paper is part of the Journal of Hydraulic Engineering, (C) ASCE, ISSN 0733-9429/05014003(9)/\$25.00. to the dam and/or the power intakes. This phenomenon takes place sporadically during yearly floods and occurs mainly during periods of peak precipitation (De Cesare 1998; De Cesare et al. 2001).

Several measures that can be taken to counter turbidity currentdriven sedimentation for storage hydropower plants have been studied by Oehy and Schleiss (2007) and Oehy et al. (2010), including obstacles that stop the current propagation or maintain particles in suspension in front of intakes to be evacuated by the turbines. Jenzer Althaus (2011) investigated the effect of rotating jet-induced flow close to intake structures on sediment mixing.

Pumped-storage operation mode may keep fine sediment suspended in the water column, as it has been shown that pumpedstorage activity alters thermal stratification, entrains organisms, and can even resuspend fine bottom sediment (Anderson 2010; Imboden 1982; Potter et al. 1982; U.S. Bureau of Reclamation 1993). Bonalumi et al. (2011) investigated how particle dynamics in high Alpine reservoirs are modified by pumped-storage operation. However, the extent of the mixing depends on the pump and turbine operations, the reservoir shape, and the design of the intake and outlet structures.

The present study evaluates the influence of pumped-storage activity on the suspended sediment concentration in pumped-storage schemes, as illustrated by a case study in Switzerland, situated at a high altitude in a glacierized catchment area, conducted to address long-term issues (sediment balance) of turbidity monitoring. Continuous real-time sediment monitoring is not novel but is far from being systematically implemented in hydropower plants. Gray and Gartner (2009) summarize different monitoring techniques for suspended sediment, focusing on river applications. Most storage hydropower applications are aimed at detection of turbidity current 
arrival in front of hydraulic outlet structures that may proceed to venting operations (Müller and De Cesare 2009). Continuous turbidity monitoring to correlate suspended particle concentration to pumping or turbine operations has not been addressed to date.

The present case study provides a description of the prototype, the turbidity sampling equipment, and the acquisition system. Temporal evolution of suspended sediment concentration is measured and analyzed, revealing both long-term variations due to seasonal changes in particle inflow and short-term changes due to hydropower operation. Finally, the sediment balance of the scheme is discussed.

\section{Site Description}

The Oberhasli region, drained by the upper Aare River, is located in the Central Alps of Switzerland [Fig. 1(a)] and hosts several interconnected reservoirs and powerhouses that are operated by Kraftwerke Oberhasli AG (KWO). The nine power plants in this region, fed by eight reservoirs, provide $8.1 \%$ of the total installed storage hydropower capacity of Switzerland and produce $10.1 \%$ of the corresponding electrical energy.

\section{Grimsel 2 Pumped-Storage Scheme}

The Grimsel 2 pumped-storage plant [Fig. 1(b)] has pumped and stored operating water between Lake Oberaar (Oa) and Grimsel (Gr) since 1982. The upper reservoir, at 2,303 $\mathrm{m}$ above sea level (a.s.1.), has a storage volume of $V_{\mathrm{Oa}}=57 \times 10^{6} \mathrm{~m}^{3}$, while the lower reservoir, at $1,909 \mathrm{~m}$ a.s.l., has a storage volume of $V_{\mathrm{Gr}}=$ $95 \times 10^{6} \mathrm{~m}^{3}$. The minimum drawdown levels of the two reservoirs are 2,250 and 1,850 $\mathrm{m}$ a.s.1., respectively, leaving water depths of 14 and $5 \mathrm{~m}$, respectively, over the center of the intake/outlet sections. The maximum discharge in turbine mode is $Q_{\text {Turb }}=$ $93 \mathrm{~m}^{3} / \mathrm{s}$ (Oa-Gr), and the maximum pumping discharge is $Q_{\text {Pump }}=80 \mathrm{~m}^{3} / \mathrm{s}$.

The power plant consists of an underground powerhouse equipped with four independent pump-turbine units with $350 \mathrm{MW}$ of total installed capacity. From Lake Oberaar, a 4-km-long headrace tunnel with an internal diameter $D=6.8 \mathrm{~m}$ connects the intake/outlet structure to a vertical surge tank $123.0 \mathrm{~m}$ in height and $13.0 \mathrm{~m}$ in diameter. From there, a 750 -m-long steel-lined shaft $(D=3.8 \mathrm{~m})$ carries the water toward the powerhouse. Downstream from the surge tank, a security butterfly valve allows the shaft to be disconnected from the upstream headrace tunnel.

\section{Sediment Characteristics}

The catchment areas of the two reservoirs are partly glaciated. Anselmetti et al. (2007) report denudation rates of 1 to $2 \mathrm{~mm} /$ year, leading to high sediment supply. The construction

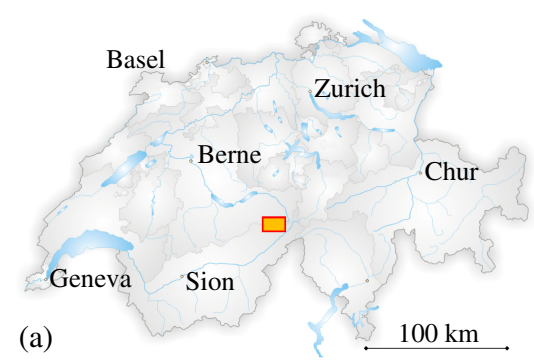

of the dams led to high retention rates of suspended sediment. Only some $40 \mathrm{kt} /$ year are released downstream of the three main KWO reservoirs (Lake Oberaar, Grimsel, and Räterichsboden), while approximately $230 \mathrm{kt} /$ year are retained. Hence, from a reservoir sedimentation point of view, a downstream sediment transfer would be desirable. If the layout of the hydraulic structures permits this downstream transfer, the turbulence generated by pumped-storage sequences could contribute by keeping fine sediment in suspension and thus increasing the efficiency of sediment transfer.

The suspended sediment characteristics of the Oberaar and Grimsel waters have been analyzed in detail by several authors. Blaser and Bühler (2001) studied the hydromechanical effect of pumps and turbines on the water turbidity, Bühler and Siegenthaler (2003) described the particle sizes and suspended sediment transport in the Grimsel region, and Bonalumi et al. (2011) investigated the particle dynamics in the reservoirs due to pumped-storage operation. Grain diameters of $d_{S}=0.2$ to $40 \mu \mathrm{m}$ were measured, with a mean diameter $d_{m}=3$ to $4 \mu \mathrm{m}$. In addition, the suspended sediment concentration varies over the course of the year between $C=50$ and $200 \mathrm{mg} / \mathrm{L}$ in the deep waters of the two reservoirs. The surface waters of Lake Oberaar rarely exhibit particle loads higher than $C=50 \mathrm{mg} / \mathrm{L}$, while the particle loads of the Lake Grimsel surface waters can reach $C=150 \mathrm{mg} / \mathrm{L}$ in summer (Bonalumi et al. 2011). Bühler et al. (2005) showed that turbidity currents arriving at the Spittellamm Dam impounding Lake Grimsel can be detected by a significant increase in turbidity in the pressurized system of the Grimsel 1 storage plant, located downstream from Lake Grimsel. At the pressure tunnel of the Grimsel 1 intake, a particle load of $C=700 \mathrm{mg} / \mathrm{L}$ was measured during a turbidity current event in 2001. The results of these studies made it possible to identify the most suitable turbidity probe and the relevant concentration spectrum to be covered by the sampling and acquisition system.

The catchments in the Grimsel region are located at high altitude and are sparsely vegetated. Thus, the glacier milk flowing into the reservoirs is characterized by a large amount of inorganic particles and a lack of nutrients. The high particle turbidity leads to a very limited light penetration into the lakes, resulting in insignificant organic matter content in the water.

Bonalumi et al. (2011) carried out periodic conductivity, temperature, and depth (CTD) sampling over two years, described the particle concentration structure of Lake Oberaar and Grimsel, and modeled the overall particle balance of the reservoirs with and without pumped-storage activity. In contrast to that study, the present case study focuses on continuous real-time monitoring of the suspended sediment concentration.

\section{Monitoring Location}

The existing KWO monitoring system at Grimsel 2 provides information about the water levels in the two reservoirs and the pump

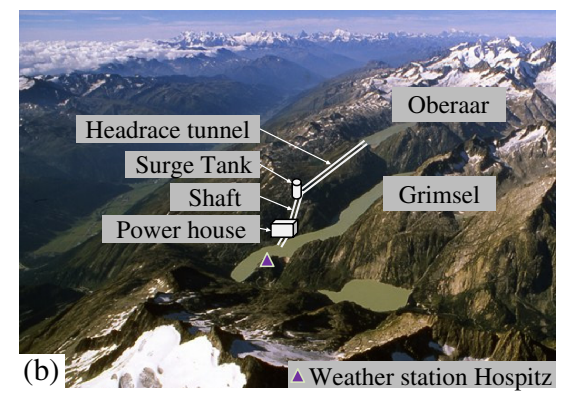

Fig. 1. (a) Location map (adapted from World of Maps 2008); (b) layout of the Grimsel 2 pumped-storage scheme (KWO Kraftwerke Oberhasli AG 2011, with permission from KWO Kraftwerke Oberhasli AG) 
and turbine discharge of each unit. All of the acquired data series are directly transmitted to the KWO command and control center. However, sediment concentration is not recorded by KWO for the inflowing rivers or in the pressurized system of the plant.

The monitoring system requires easy access to the steel-lined pressure shaft, but for the turbidity measuring equipment, low pressure at the inflow section is needed. Therefore, suitable monitoring locations are limited to the security butterfly valve chamber near the surge tank and the tunnel downstream from the powerhouse. Low temperatures and low humidity in the valve chamber provide optimal conditions for electronic data acquisition devices. Therefore, the monitoring system was installed on the accessible reach of the steel liner just downstream from the surge tank, where a drainage bypass provides an opportunity for direct water sampling.

\section{Sampling and Data Acquisition}

\section{Turbidity Sensor and Calibration}

From the sampling location in the shaft, $Q=1$ to $2 \mathrm{~L} / \mathrm{s}$ of water pass through the pressure regulating valve and the deaerator to the measuring cylinder [Fig. 2(a)], where turbidity is measured by a Cosmos 25-E probe (Züllig AG, Switzerland). The water then flows toward a sewer in the drain below the steel liner. Periodic purging of the measuring cylinder permits removal of sediment deposits from its bottom.

The Cosmos 25-E probe needs only one calibration point in the application range of the expected turbidity values at Grimsel 2. During the calibration period, turbidity TU (FNU) was measured by the probe, and the corresponding value was saved by the amplifier described later. At the same time, three water samples were taken from the shaft. These water samples were then analyzed by the Swiss Federal Institute of Aquatic Science and Technology (Eawag) using a repetitive and robust filtering method. Water samples were passed through a filter that retained particles larger than $0.4 \mu \mathrm{m}$. After the filtering process, the filter was dried and weighed for determination of the sediment mass contained in the sampled volume using a Mettler AT 460 Delta Range (Mettler-Toledo Ltd., Greifensee, Switzerland) balance with an accuracy of $0.1 \mathrm{mg}$. This procedure was repeated three times per water sample to obtain a reliable estimate of the suspended sediment concentration $C(\mathrm{mg} / \mathrm{L})$. The value $C(\mathrm{mg} / \mathrm{L})$ corresponding to the calibration period could then be entered into the amplifier device that then attributes it to the turbidity value TU (FNU) registered during the calibration period. From there, a linear relation given by the manufacturer allows the device to calculate the suspended sediment concentration from the measured turbidity value, with a measurement error smaller than $2 \%$. As the organic matter content is insignificant in the waters of the Grimsel region, it is not expected to influence the results of the filtering method or the conversion from turbidity to concentration.

Over the course of the monitoring period, validation samples were taken twice to repeat the filtering procedure at Eawag and confirm that the concentration value calculated by the device correctly represented the suspended sediment concentration in the system.

\section{Acquisition System}

The turbidity sensor is connected to a $b$-line II amplifier [Züllig AG, Switzerland; Fig. 2(b)] that generates an output signal between 4 and $20 \mathrm{~mA}$, which is correlated with a user-defined turbidity range. The upper limit of the sediment concentration was initially set to $C=1,000 \mathrm{mg} / \mathrm{L}$ to record eventual increases in the sediment concentration due to annual flood and turbidity current events in the summer, as observed by Bühler et al. (2005). After the first 2 months of measurement, the upper limit was reset to $300 \mathrm{mg} / \mathrm{L}$ because the sediment load is smaller in the winter and spring than in the summer.

The signal from the amplifier is transmitted to a data acquisition system [Fig. 2(c)] composed of a signal conditioner, a NI-USB6259 M series acquisition card (National Instruments Switzerland, Ennetbaden, Switzerland), and an industrial computer (Kontron Compact Computers AG, Luterbach, Switzerland). A LabVIEWbased data acquisition tool sampled and stored data at a frequency of $f=0.2 \mathrm{~Hz}$ every $30 \mathrm{~min}$. The program starts the storage loop by opening a. $t d m s$ file with a date and time assigned according to the PC clock, synchronized with the KWO server. A virtual private networking (VPN) Internet connection is used for online control and data downloads.

\section{Monitoring Data and Results}

Suspended sediment concentration data are available for almost the entire sampling period. One major interruption began at the end of December 2010, when maintenance work at the monitoring location led to a shutdown of the entire system until February 2011. On three occasions, measurements were briefly stopped to adjust the acquisition system and interface, which resulted in a lack of data for 1- to 3-day periods. On April 30, the sampling valve on the pressurized shaft started to clog with sediment and lost its functionality completely for 10 days, until a cleaning intervention could be performed. On July 4, a technical problem required that the monitoring

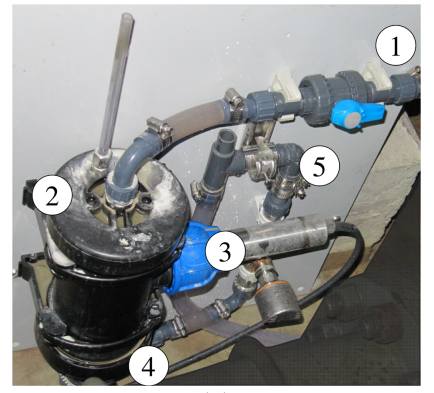

(a)

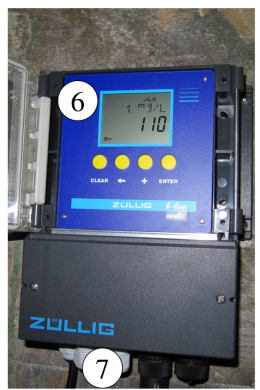

(b)

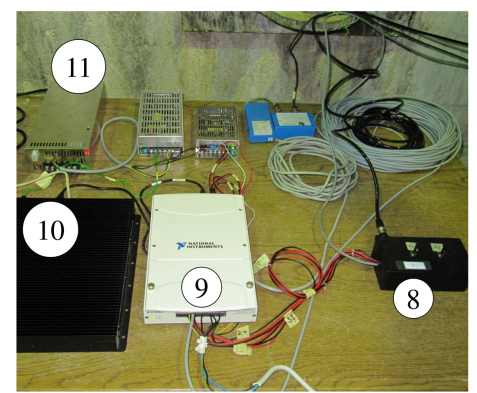

(c)

Fig. 2. (a) Turbidity measuring equipment; (b) signal amplifier $b$-line II; (c) data acquisition equipment at Grimsel 2: 1, inlet; 2 , measuring cylinder; 3 , Cosmos 25-E probe; 4, purge valve; 5, outlet toward the sewer; 6, real-time suspended sediment concentration display; 7, power input and signal output toward the acquisition system; 8, signal conditioner; 9, acquisition card; 10, computer; and 11, power supply 
Table 1. Measurement Periods with Indications of Reliable Turbidity Sampling Days, Monthly Means of Suspended Sediment Concentration $C_{m}$, and Ranges of Suspended Sediment Concentration Ratios between Pumping and Turbine Sequences $C_{m, \text { Pump }} / C_{m, \text { Turb }}$

\begin{tabular}{lcc}
\hline Measurement period & $\begin{array}{c}\text { Monthly mean } \\
C_{m}(\mathrm{mg} / \mathrm{L})\end{array}$ & $\begin{array}{c}\text { Range of } \\
C_{m, \text { Pump }} / C_{m, \text { Turb }}\end{array}$ \\
\hline October 2010 (6 days of data) & 91.90 & $0.95-1.02$ \\
November 2010 (30 days of data) & 81.47 & $0.96-1.02$ \\
December 2010 (19 days of data) & 79.55 & $0.96-1.04$ \\
January 2011 (no records) & - & - \\
February 2011 (14 days of data) & 61.15 & $0.97-1.05$ \\
March 2011 (29 days of data) & 55.47 & $0.94-1.04$ \\
April 2011 (30 days of data) & 60.11 & $0.93-1.11$ \\
May 2011 (16 days of data) & 83.98 & $0.93-1.16$ \\
June 2011 (30 days of data) & 75.96 & $0.93-1.09$ \\
\hline
\end{tabular}

be stopped. As a result, reliable data are available for 174 days between October 26, 2010, and June 30, 2011 (Table 1).

The turbidity signal was smoothed by a moving average over 60 time steps, corresponding to $5 \mathrm{~min}$ of sampling. The phenomenon of oscillating disturbances is linked to the very small particles in the sampled water (glacier milk), as reported by the manufacturer for previous in situ applications. However, calibration and validation samples showed that the turbidity probe worked properly under the case study conditions.

\section{Pumped-Storage Operation}

Annually, $V=600$ to $700 \times 10^{6} \mathrm{~m}^{3}$ water are pumped from Lake Grimsel to Lake Oberaar and moved back during turbine mode. Thus, the volumes of water in the lower and upper reservoirs are exchanged 6 to 10 times over the course of 1 year. During the monitoring period, $V_{\text {Turb }}=419.6 \times 10^{6} \mathrm{~m}^{3}$ and $V_{\text {Pump }}=420.8 \times$ $10^{6} \mathrm{~m}^{3}$ were moved by pumping and turbine operations, respectively. The weekly water volumes transferred ranged between $V_{\text {Pump,Turb }}=5$ and $23 \times 10^{6} \mathrm{~m}^{3}$ (Fig. 3).

The Lake Oberaar level was highest during mid-November 2010, when it reached 2,302 $\mathrm{m}$ a.s.l., while the Grimsel reservoir level was highest at the end of November, at 1,906 m a.s.l. Low levels of approximately 2,260 (Oa) and 1,862 m a.s.l. (Gr) were measured several times in April and May 2011. From October to March, the weekly levels varied from 2 to $12 \mathrm{~m}$ in Lake Oberaar and from 2 to $6 \mathrm{~m}$ in Lake Grimsel. During periods of low reservoir levels, weekly variations of up to $18(\mathrm{Oa})$ and $12 \mathrm{~m}(\mathrm{Gr})$ were recorded.

\section{Meteorological Data}

In the Oberhasli region, rainfall and particularly snowmelt are the main causes of increased particle inflow into the reservoirs. Bonalumi et al. (2011) defined four characteristic particle inflow periods: no inflow, when both reservoirs are covered with ice (November to May \pm 2 weeks); high inflow during the snowmelt period (May to August); low particle inflow during the fall (September, October); and peak particle inflow during heavy rain events in the summer.

Knowledge of meteorological conditions is thus relevant to forecasting periods of high suspended sediment concentration. Therefore, data on the air temperature $T_{a}$, precipitation $P$, and snow height were obtained from the "Grimsel Hospitz" weather station next to the Spittellamm Dam [Fig. 1(b), Swiss Federal Office of Meteorology and Climatology, MeteoSwiss]. In addition, daily inflows from the catchment areas (KWO) were considered. Fig. 4 presents meteorological data for a selected period from March 28 to June 20, corresponding to the period of the main changes in the observed suspended sediment concentration.

Due to warm weather in the early spring, the main snowmelt in 2011 occurred in March and April. Three significant peaks in the natural inflow were observed during the weeks of May 9 to 16, May 23 to 30, and June 13 to 20 .

\section{Suspended Sediment Concentration}

The suspended sediment concentration $C$ varied over the measurement period, with monthly means of approximately $C_{m}=$ $80 \mathrm{mg} / \mathrm{L}$ in November and December, decreasing to $C_{m}=55$ to $60 \mathrm{mg} / \mathrm{L}$ between February and April, and increasing again to $C_{m}=80 \mathrm{mg} / \mathrm{L}$ in May and June (Table 1). In addition, short-term variations were observed during pumping and turbine sequences. To describe these variations, the mean concentration measured during a pumping sequence $C_{m \text {.Pump }}$ was compared to the mean concentration $C_{m \text {,Turb }}$ during the preceding and subsequent turbine sequences. Thus, 5 to 10 values for the ratio $C_{m \text {.Pump }} / C_{m \text {.Turb }}$ were obtained per week, depending on the number of pumping sequences. The ranges of the calculated ratios between the suspended sediment concentrations in pumping and turbine mode are shown in Table 1.

Figs. 5 and 6 present four monitoring charts that illustrate the main observations during the measurement period. From October to December, the reservoir levels were high, the variation in the levels was relatively small [Figs. 5(a and b)], and the particle load fluctuated around $C_{m}=80 \mathrm{mg} / \mathrm{L}$, independent of the pumping and turbine sequences [Figs. 5(c and d)]. The concentration then started to decrease until the two lakes were covered with ice and inversely stratified and the natural sediment inflow was at its lowest. By the end of March, the Lake Grimsel level had fallen to $1,866 \mathrm{~m}$ a.s.l., just $18 \mathrm{~m}$ above the minimum drawdown elevation [Fig. 5(f)]. During the first 2 weeks of April, the pumpedstorage cycles started to be reflected in the suspended sediment concentrations [Fig. 5(g and h)]. More turbid water was pumped up into Lake Oberaar, with concentrations up to $11 \%$ higher than during turbine operation.

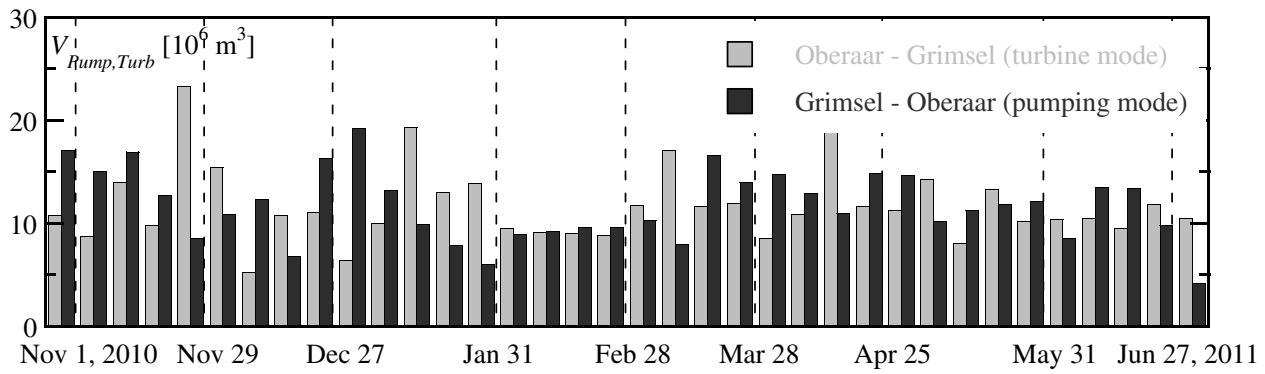

Fig. 3. Weekly volumes $V_{\text {Pump,Turb }}$ operated by the Grimsel 2 pumped-storage plant during the entire monitoring period from October 26 , 2010 to June 30, 2011 


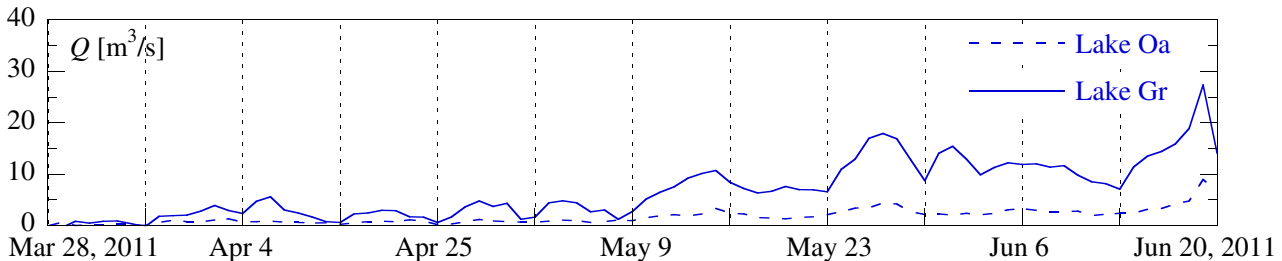

(a)

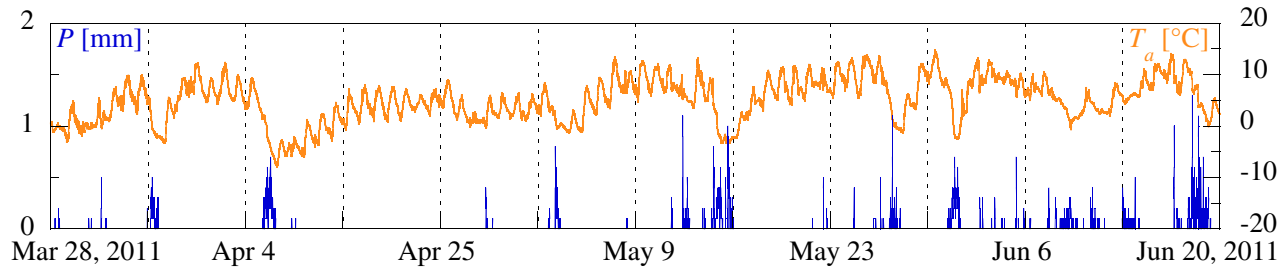

(b)

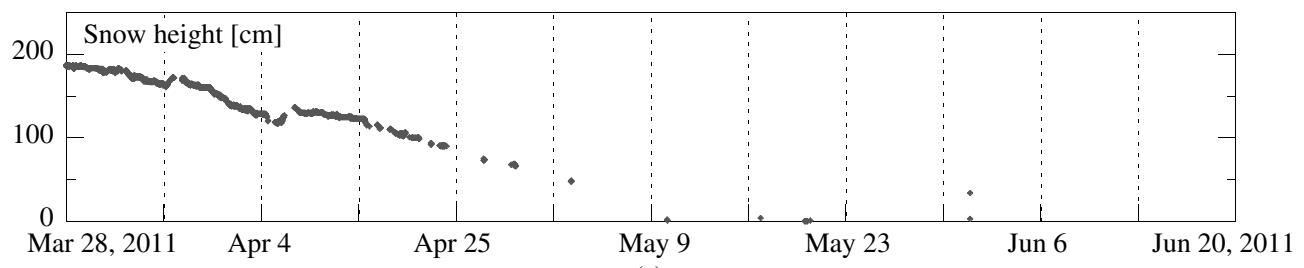

(c)

Fig. 4. Data series of (a) natural inflow $Q$ to Lakes Grimsel and Oberaar; (b) air temperature $T_{a}$ and precipitation $P$; (c) snow height at weather station Grimsel Hospitz for the monitoring period from March 28, 2011 to June 20, 2011 (Data from KWO Kraftwerke Oberhasli AG 2011 and Federal Office of Meteorology and Climatology MeteoSwiss 2011)

By the end of April and with ongoing snowmelt, the mean suspended sediment concentration again increased to approximately $C_{m}=80 \mathrm{mg} / \mathrm{L}$. During the first three pumping sequences in the week of May 16 to 23, the suspended sediment concentration was up to $16 \%$ higher than in the preceding and subsequent turbine cycles [Fig. 6(c)], at $C_{\max }=100 \mathrm{mg} / \mathrm{L}$. Again, the Lake Grimsel level, at 1,864 m a.s.l., was very low at that time [Fig. 6(b)]. As the lake levels increased, the difference in the particle loads between the pumping and turbine modes decreased.

On the one hand, these two observation examples of increased particle load during pumping mode occurred during the snowmelt in April and 2 days after a considerable increase in the natural inflow into Lake Grimsel in May. These events are believed to have increase particle load in the water body. Thus, the higher concentrations in the pumped water were at least affected by meteorological conditions. However, the suspended sediment concentrations recorded in other weeks do not show a similar sensitivity to meteorological conditions.

On the other hand, the reservoir level plays an important role, as in both cases, the ratio of the suspended sediment concentrations in pumping and turbine mode $C_{m \text {.Pump }} / C_{m \text {.Turb }}$ was high when the level of Lake Grimsel was low. As the water level rose, the effect decreased again. When the Lake Oberaar level dropped to the lowest values recorded during the monitoring period [Fig. 6(e)], the response of the suspended sediment concentration was reversed, and systematically higher particle loads occurred in turbine mode [Figs. 6(g and h)].

\section{Discussion}

Sampling of the suspended sediment concentrations in an Alpine pumped-storage system permitted the detection of seasonal increases and decreases in the particle load in the pump- or turbineoperated water. Thus, the arrival of turbidity currents near the intake/outlet area could also be predicted by drastic increases in sediment concentrations within short periods of time. As no such important event was recorded during the monitoring period, this aspect is not discussed further. Hereafter, the sediment balance of the studied Grimsel 2 scheme and the correlation between suspended sediment concentration and pumped-storage sequences is discussed.

\section{Sediment Balance of the Grimsel 2 Scheme}

Turbidity records permit direct estimation of the transported suspended sediment volumes from one reservoir to the other. The weekly volumes moved $V_{S}$ and the evolution of the weekly sediment balance over the entire sampling period are presented in Fig. 7.

These volumes were calculated assuming a density of $\rho_{s}=$ $1,500 \mathrm{~kg} / \mathrm{m}^{3}$ (Bühler et al. 2004). Volume estimates for weeks during which turbidity sampling was restricted but during which at least $126 \mathrm{~h}$ of reliable records were available were completed using values calculated based on real pumping or turbine discharge and average turbidity values for the previous or following day. On two occasions, concentration data were only available for short periods of 54 and $58 \mathrm{~h}$ during weekends, during the weeks of February 7-14 and May 9-16 (marked WE in Fig. 7). Neither the period from December 27 to February 7 nor the period from May 5 to 14 were taken into account in the sediment balance estimation because the turbidity sensor was not functioning correctly during those periods.

Even though there were large differences in the weekly sediment transfer, the transport between the two lakes was balanced over the 8-month monitoring period, with a total suspended sediment mass of $M_{S, \mathrm{Oa}-\mathrm{Gr}}=22.2 \mathrm{kt}$ transferred from the upper reservoir into the lower reservoir and $M_{S, \mathrm{Gr}-\mathrm{Oa}}=23.0 \mathrm{kt}$ pumped up from Lake Grimsel into Lake Oberaar. For the aforementioned density of $\rho_{s}=1,500 \mathrm{~kg} / \mathrm{m}^{3}$, this corresponds to total volumes of $V_{S, \mathrm{Oa}-\mathrm{Gr}}=14,820$ and $V_{S, \mathrm{Gr}-\mathrm{Oa}}=15,306 \mathrm{~m}^{3}$. Consequently, 


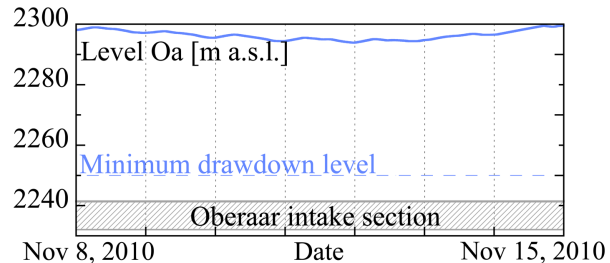

(a)

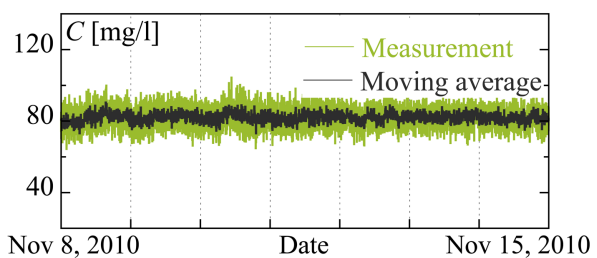

(b)

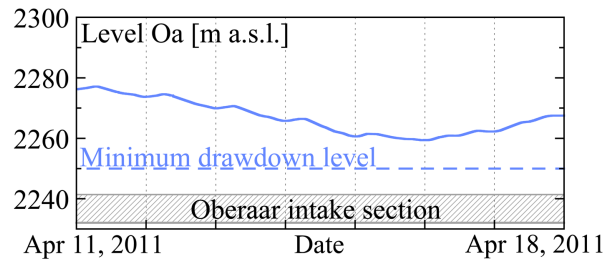

(c)

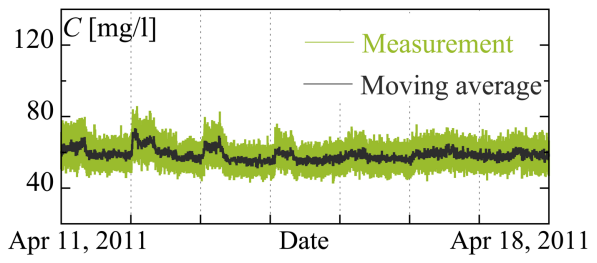

(d)

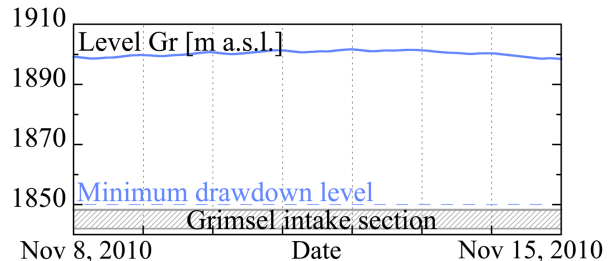

(e)

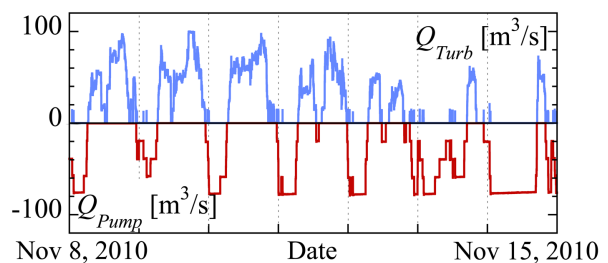

(f)

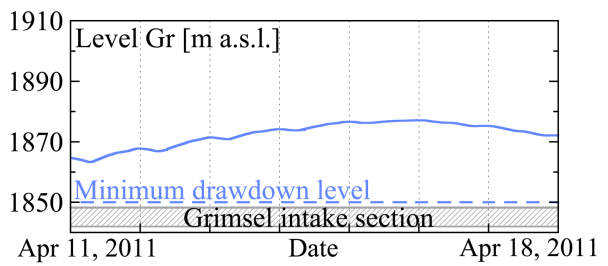

(g)

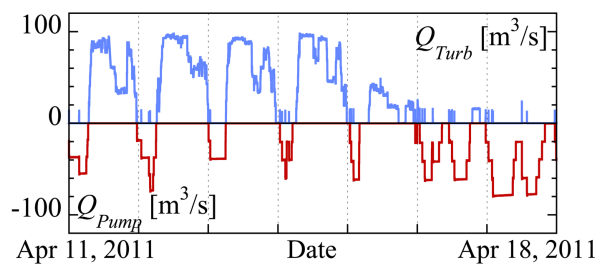

(h)

Fig. 5. Weekly monitoring plots for measurement periods from (a-d) November 8-15, 2010; (e-h) April 11-18, 2011: temporal evolution of reservoir levels of (a and e) Lake Oberaar (Oa) and (b and f) Lake Grimsel (Gr); (c and g) measured suspended sediment concentration $C$; and (d and h) pumped and turbined discharge $Q_{\text {Pump }}$ and $Q_{\text {Turb }}$

the difference in transferred volumes for the two operation directions is $\Delta V_{S} \approx 0$.

Anselmetti et al. (2007) reported total sedimentation rates for Lake Oberaar and Grimsel of 22,200 and 74,650 $\mathrm{m}^{3}$, respectively. Bonalumi et al. (2011) calculated a natural annual inflow of suspended sediment of 6.6 for Oberaar and $51.2 \mathrm{kt} /$ year for Grimsel, based on periodic in situ CTD measurements over 2 years. A comparison with these values underscores how much suspended sediment is constantly moved up and down by the Grimsel 2 plant. A mass corresponding to almost seven times the suspended sediment inflow to Lake Oberaar calculated by Bonalumi et al. (2011) was transported between the two reservoirs during the monitoring period. The suspended sediment volumes moved between the two lakes reached 130 and $40 \%$ of the annual deposited volumes in the upper and lower reservoirs, respectively. If the volume kept in suspension by the pumped-storage operations were to contribute to the filling of Lake Oberaar or Lake Grimsel, volumes corresponding to 0.26 or $0.15 \%$ of the reservoir volumes, respectively, would be lost. These values are on the same order of magnitude reported by Beyer Portner and Schleiss (2000) for observed natural sedimentation processes in Swiss reservoirs.

On an annual scale, sediment exchange will increase because the 8-month balance will be completed with sediment input during the summer months, during which approximately $70 \%$ of the sediment inflow into the reservoirs usually occurs. Consequently, sediment volumes transported annually between the two lakes are expected to be higher than reported in this case study.
However, measurements show that a considerable amount of the sediment from pumping is moved back to the lower reservoir during turbine mode. Thus, pumped-storage activity does not increase the actual sedimentation rate of the reservoirs. The pumpedstorage-generated turbulence is sufficient to keep most of the fine sediment in suspension. Periods of no operation, when neither the pumps nor the turbines are working, could lead to settling of sediment and thus influence the sediment balance. Knowledge of the sediment quantities moved in the pressurized system not only permits determination of the sediment balance and thus the sedimentation rates of the reservoirs but also may make it possible to predict when maintenance of the mechanical equipment, which is exposed to high levels of abrasion due to high sediment concentrations, will be required.

\section{Response of Suspended Sediment Concentration to Pumped-Storage Operation}

The suspended sediment load in the pump and turbine water depends on the particle concentration in the two reservoirs and is therefore linked to meteorological conditions, mainly snowmelt and rainfall events, which govern the net particle inflow to the lakes. If one reservoir has a considerably higher concentration in front of the intake/outlet structure, the suspended sediment load will initially be different for the two operation modes and perceptible in the monitoring plots. This difference will remain until the particle concentrations in the reservoirs have been equilibrated. 


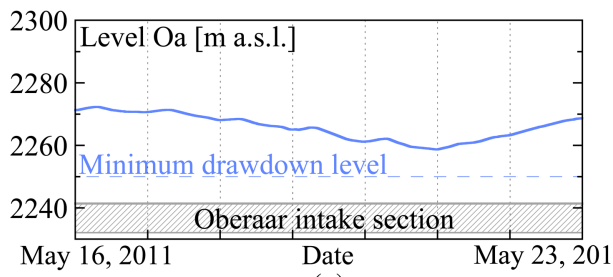

(a)

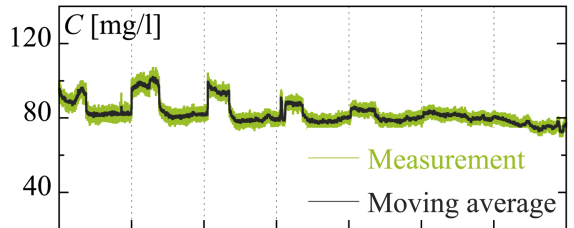

May 16, 2011

(b)

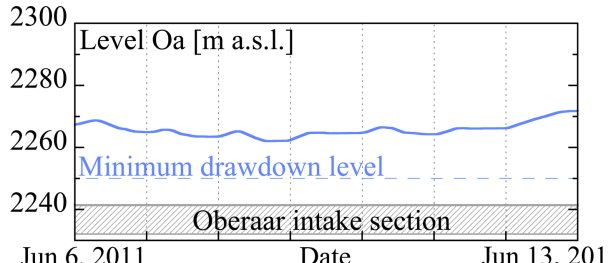

(c)

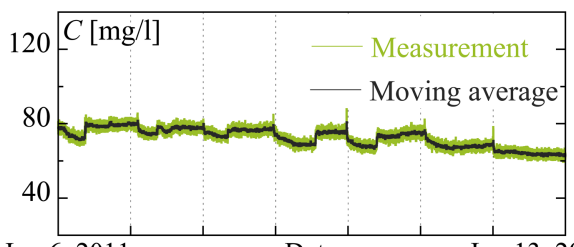

(d)

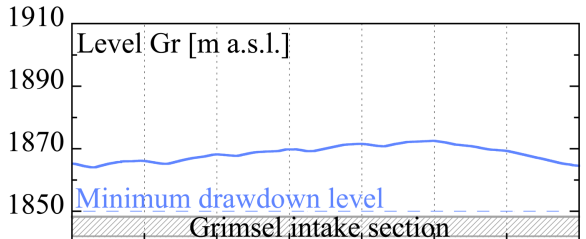

May 16, 2011 Date

(e)

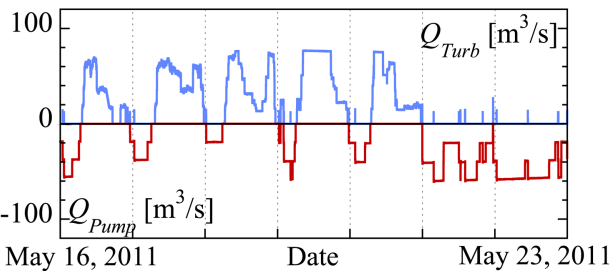

(f)

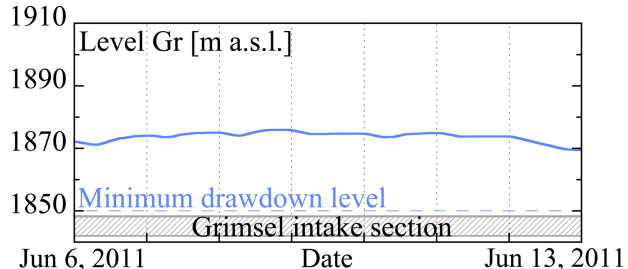

(g)

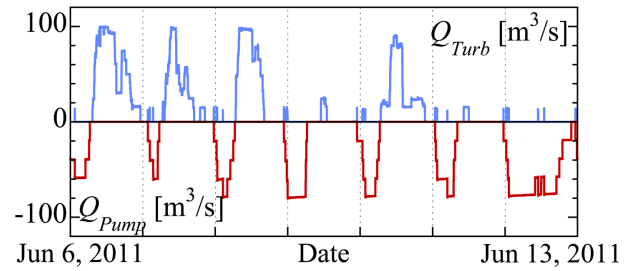

(h)

Fig. 6. Weekly monitoring plots for measurement periods from (a-d) May 16-23, 2011; (e-h) June 6-13, 2011: (a and e) temporal evolution of reservoir levels of Lake Oberaar (Oa) and (b and f) Lake Grimsel $(\mathrm{Gr})$; (c and g) measured suspended sediment concentration $C$; (d and h) pumped and turbined discharge $Q_{\text {Pump }}$ and $Q_{\text {Turb }}$

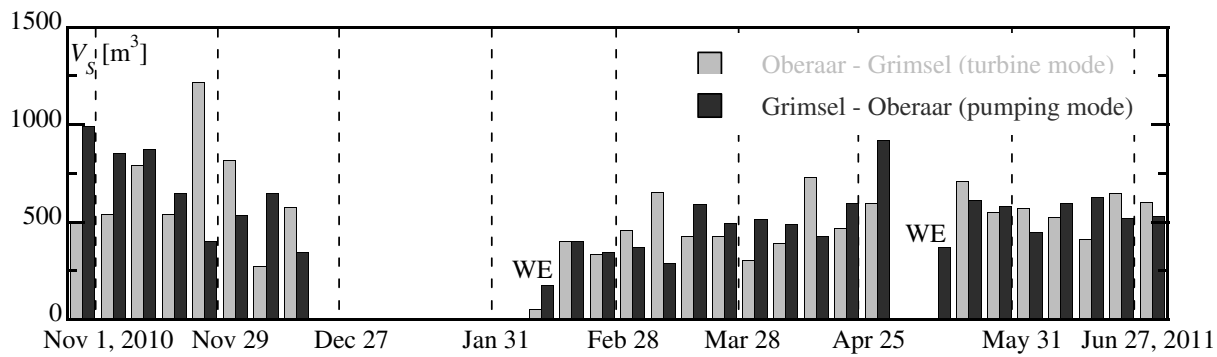

(a)

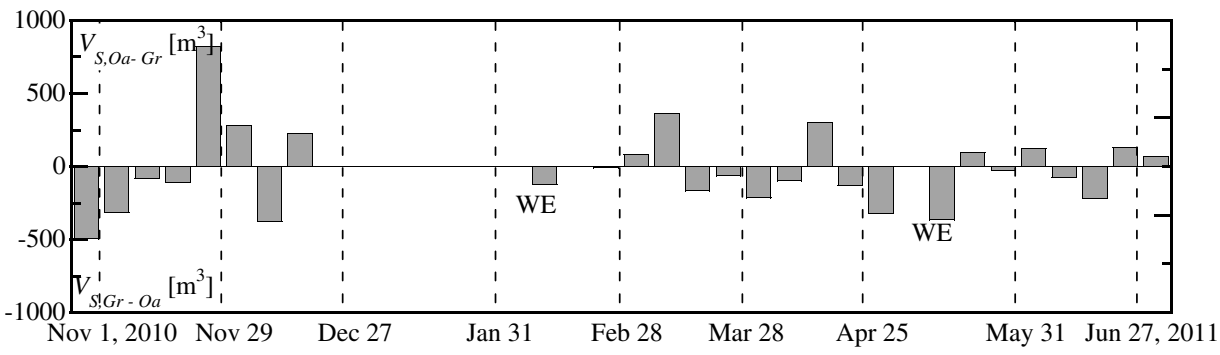

(b)

Fig. 7. (a) Sediment volumes $V_{S}$ transferred during pumping (Gr-Oa) and turbine mode (Oa-Gr); (b) sediment balance over the sampling period from October 26, 2010, to June 30, 2011 


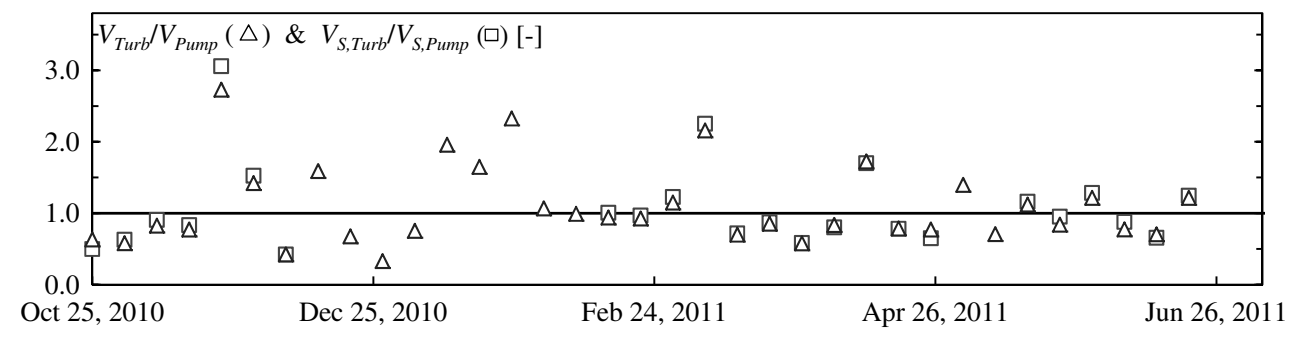

Fig. 8. Volume ratios of the water-sediment mixture $V_{\text {Turb }} / V_{\text {Pump }}$ (calculated based on discharge data provided by KWO, with permission) and suspended sediment $V_{S, \text { Turb }} / V_{S \text {,Pump }}$ (computed based on turbidity measurements) for the sampling period from October 26, 2010 to June 30,2011

However, for similar initial concentrations $C_{0}$, the ratio between the suspended sediment concentrations in pumping and turbine mode $\left(C_{m, \text { Pump }} / C_{m \text {,Turb }}\right.$, Table 1$)$ is driven by parameters other than $C_{0}$. The monitoring plots revealed high $C_{m \text {,Pump }} / C_{m \text {,Turb }}$ ratios for periods of low particle loads of approximately $C_{m}=60 \mathrm{mg} / \mathrm{L}$, as well as for $C_{m}=80 \mathrm{mg} / \mathrm{L}$.

The measurements obtained in this study indicate that the reservoir level is the main parameter associated with the differences between the pumping and turbine modes. For the late autumn and winter, during which the reservoir levels are high, no direct correlation between pumped-storage sequences and suspended sediment concentrations in the transported water can be detected. When the reservoir levels are low in the spring, the suspended sediment concentration is dependent on the pumping and turbine operations. The maximum and minimum ratios were $C_{m, \text { Pump }} / C_{m, \text { Turb }}=1.16$ and 0.93, respectively. High ratios, which indicate higher concentrations in the pump water, were measured when the Grimsel reservoir level was below approximately $1,870 \mathrm{~m}$ a.s.l., which corresponds to an intake submersion of less than $22 \mathrm{~m}$. Low ratios were observed when the Lake Oberaar level dropped below approximately 2,268 $\mathrm{m}$ a.s.1., corresponding to an intake submersion of less than $36 \mathrm{~m}$. The suspended sediment concentration in front of the intake/ outlet zone appears to have been highest when the water levels were low, due to increased turbulent mixing.

When the average particle load is the same during the pumping and turbine modes, sediment transfer between the two reservoirs is mainly dependent on storage management. However, even weeks with high or low concentration ratios $C_{m \text {,Pump }} / C_{m \text {,Turb }}$ had rather equilibrated sediment balances. Fig. 8 illustrates this observation and compares the volume ratio of the suspended sediment $C_{m, \text { Pump }} / C_{m, \text { Turb }}$ to the water-sediment mixture $V_{\text {Turb }} / V_{\text {Pump }}$ exchanged by the Grimsel 2 plant. Values of $V_{\text {Turb }} / V_{\text {Pump }}<1.0$ indicate that more water is pumped upward into Lake Oberaar than is turbined in the other direction.

During 16 of the 24 monitored weeks, more water and sediment were pumped from Lake Grimsel into Lake Oberaar. Nevertheless, the sediment balance was equilibrated over the length of the monitoring period. Thus, the sediment balance depends on the frequency and magnitude of the pumped-storage cycles.

Monitoring the turbidity in the pressurized system and establishing a correlation between the suspended sediment concentration and hydropower operation provides knowledge on how suspended sediment transport can be affected by plant operations. Thus, the plant operator may be able to actively influence the sediment transport phenomena by the choice of operations.

\section{Conclusions}

Sedimentation is a major concern for many storage reservoirs and endangers the storage reliability, operational safety, and efficiency of hydropower schemes. This case study presents the results of continuous measurement of the suspended sediment concentration in the water passing through the Grimsel 2 pumped-storage plant. A turbidity probe was installed on the upstream part of the pressurized shaft, and an acquisition system provided data storage, remote access, and real-time data display.

The sediment load transferred during pumped-storage operation depends on the reservoir level as well as the sediment yield from the catchment area. Snowmelt, heavy rainfall, and low reservoir levels increase suspended sediment in the operated water. The data collected at the Grimsel 2 plant reveal a mean suspended sediment concentration between $C_{m}=55$ and $85 \mathrm{mg} / \mathrm{L}$ in the pressurized system, with major changes in $C_{m}$ between the late autumn, winter, and spring months. In case of pumped-storage plants, the suspended sediment concentration correlates with the pumped-storage sequences, especially when reservoir levels are low. Under such conditions, suspended sediment concentrations are highest in the intake/outlet zone. Periods with higher particle loads during pumping mode are observed more frequently.

High turbidity in front of the water intakes leads to significant quantities of sediment being moved. Compared to the annual sedimentation rates of the two Lakes Oberaar and Grimsel, the sediment volumes moved by the pumped-storage operations are considerably high. However, most of the suspended sediment volume entering the upper reservoir is transported back during turbine mode, which leads to an equilibrated suspended sediment balance over the 8-month monitoring period. Consequently, pumpedstorage activity for the observed conditions does not increase the actual sedimentation rate of the reservoirs. Mixing processes allow most of the fine sediment to remain in suspension in front of the intake/outlet structures. By slowing down the settling of fine sediment, continuous pumped-storage operation could contribute to increased downstream transfer of suspended sediment, if the latter can be ensured by a sluice opening or a bottom outlet close to the intake/outlet structure.

The sediment balance remains in equilibrium only as long as the turbine and pump operations have similar durations and as long as the sediment concentrations in the storage volumes are equal. Pumping of suspended sediment from a river or watershed with high erosion may lead to considerable sediment supply to the upstream lake and thus to reservoir sedimentation.

With the tested sediment monitoring system, the plant operator can detect an increasing sediment load in the pressure shaft, indicating a high sediment load in front of the intake/outlet structure, and can adapt the operation to actively manage reservoir sedimentation. For example, after the arrival of a turbidity current in front of the intake/outlet structure, the plant operator could choose not to run the turbines or pumps but rather to proceed to a downstream transfer of the sediment-laden flow, if bottom outlets are located close to the intake/outlet zone. Alternatively, the operator could employ increased pumped-storage operation to guarantee increased 
mixing of the water column. Evidently, electricity prices will always constrain such operational measures. In addition to providing short-term information, the turbidity monitoring system makes it possible to establish a continuous sediment balance for long-term monitoring issues and thus plan appropriate intervention.

\section{Acknowledgments}

This research was conducted in the framework of the HydroNet consortium funded by the Competence Center Energy and Mobility (CCEM), swisselectric research and the Swiss Federal Office of Energy (SFOE-hydropower research). Prototype measurements were kindly supported by the Kraftwerke Oberhasli AG.

\section{Notation}

The following symbols are used in this paper:

$C=$ suspended sediment concentration $(\mathrm{mg} / \mathrm{L})$;

$D=$ diameter $(\mathrm{m})$;

$d_{m}=$ mean particle diameter $(\mu \mathrm{m})$;

$d_{s}=$ diameter of the particle $(\mathrm{m})$;

$f=$ frequency $(\mathrm{Hz})$;

$M=\operatorname{mass}(\mathrm{kg}),(\mathrm{t})$;

$P=$ precipitation $(\mathrm{mm})$;

$Q=$ discharge $\left(\mathrm{m}^{3} / \mathrm{s}\right),(1 / \mathrm{s}) ;$

$T=$ temperature $\left({ }^{\circ} \mathrm{C}\right)$;

$\mathrm{TU}=$ turbidity $(\mathrm{FNU})$;

$V=$ volume $\left(\mathrm{m}^{3}\right)$

$\Delta=$ difference (-); and

$\rho=$ density $\left(\mathrm{kg} / \mathrm{m}^{3}\right)$.

\section{Indices}

$$
\begin{aligned}
a & =\text { air, wind; } \\
\mathrm{Gr} & =\text { grimsel; } \\
i & =\text { intake; } \\
m & =\text { mean; } \\
\max & =\text { maximum; } \\
\mathrm{Oa} & =\text { oberaar; } \\
\text { Pump } & =\text { pumping; } \\
S & =\text { sediment or solid; } \\
\text { Turb } & =\text { turbine; and } \\
0 & =\text { initial. }
\end{aligned}
$$

\section{References}

Anderson, M. A. (2010). "Influence of pumped-storage hydroelectric plant operation on a shallow polymictic lake: Predictions from 3-D hydrodynamic modeling." Lake Reservoir Manage., 26(1), 1-13.

Anselmetti, F., et al. (2007). "Effects of Alpine hydropower dams on particle transport and lacustrine sedimentation." Aquat. Sci., 69(2), 179-198.

Beyer Portner, N., and Schleiss, A. J. (2000). "Bodenerosion in alpinen Einzugsgebieten in der Schweiz." Wasserwirtschaft, 90(3), 88-92 (in German).

Blaser, S., and Bühler, J. (2001). "Werden durchlaufende Sedimentpartikel in hydraulischen Maschinen fragmentiert?" Wasser, Energie, Luft-eau, énergie, air, 93(11), 305-311 (in German).

Bonalumi, M., Anselmetti, F. S., Kaegi, R., and Wüest, A. (2011). "Particle dynamics in high-Alpine proglacial reservoirs modified by pumpedstorage operation." Water Resour. Res., 47(9), W09523.
Bühler, J., and Siegenthaler, C. (2003). "Veränderungen im Oekosystem Brienzersee. Teilprojekt 3.2: Korngrössenverteilung, Zusammensetzung und Transport von Schwebstoffen im Grimselgebiet." Report, Amt für Gewässerschutz, und Abfallwirtschaft des Kantons Bern (GSA), Bern, Switzerland (in German).

Bühler, J., Siegenthaler, C., Simitovic, R., Wüest, A., and Zeh, M. (2004). “Trübeströme im Grimselsee." Wasser, Energie, Luft-eau, énergie, air, 96(5), 129-135 (in German).

Bühler, J., Siegenthaler, C., and Wüest, A. (2005). "Turbidity currents in an alpine pumped-storage reservoir." Proc., 4th Int. Symp. on Environmental Hydraulics and 14th Congress of Asia and Pacific Division, International Association of Hydraulic Engineering and Research, 239-244.

De Cesare, G. (1998). "Alluvionnement des retenues par courants de turbidité." A. Schleiss, ed., Thesis 1820, Communication No. 7 du Laboratoire de constructions hydrauliques, Ecole Polytechnique Fédérale de Lausanne, Lausanne, Switzerland (in French).

De Cesare, G., Schleiss, A. J., and Hermann, F. (2001). "Impact of turbidity currents on reservoir sedimentation." J. Hydraul. Eng., 10.1061/ (ASCE)0733-9429(2001)127:1(6), 6-16.

Fan, J., and Morris, G. L. (1992). "Reservoir sedimentation II: Reservoir desiltation and long-term storage capacity.” J. Hydraul. Eng., 10.1061/ (ASCE)0733-9429(1992)118:3(370), 370-384.

Federal Office of Meteorology, and Climatology MeteoSwiss. (2011). "IDAweb." The data portal of MeteoSwiss for research and teaching, 〈http://www.meteoswiss.ch〉 (Oct. 5, 2011).

Gray, J. R., and Gartner, J. W. (2009). "Technological advances in suspended-sediment surrogate monitoring." Water Resour. Res., 45(4), W00D29.

Hartmann, S. (2007). "Interreg IIIB_-Ver-und Entlandung von Stauräumen im Alpengebiet." Wasserwirtschaft, 97(4), 31-35 (in German).

Imboden, D. (1982). "The impact of pumped storage operation on the vertical temperature structure in a deep lake: A mathematical model." Proc., Clemson Workshop on Environmental Impacts of Pumped Storage Hydroelectric Operations, J. P. Clugston, ed., 125-146.

Jenzer Althaus, J. (2011). "Sediment evacuation from reservoirs through intakes by jet induced flow." Thesis 4927, Communication No. 45 du Laboratoire de constructions hydrauliques, A. Schleiss, ed., Ecole Polytechnique Fédérale de Lausanne, Lausanne, Switzerland.

Jenzer Althaus, J., De Cesare, G., and Hauenstein, W. (2005). "Nachhaltiges Sedimentmanagement in alpinen Speichern, EU-Projekt 'ALPRESERV' im Rahmen von Interreg III B." Wasser, Energie, Luft-eau, énergie, air, 97(3), 77-78 (in German).

Knoblauch, H., Hartmann, S., and De Cesare, G. (2005). "Sediment management an alpinen Speichern: Das EU-INTERREG IIIB Projekt ALPRESERV." Österreichische Wasser-und Abfallwirtschaft, 57(11), 185-190 (in German).

KWO Kraftwerke Oberhasli AG. (2011). "Electrical energy." Power plants and dams, 〈http://www.kwo.ch〉 (Mar. 31, 2011).

Müller, P. J., and De Cesare, G. (2009). "Sedimentation problems in the reservoirs of the Kraftwerke Sarganserland-Venting of turbidity currents as the essential part of the solution." Proc. (on CD) of the $23 \mathrm{rd}$ Congress of the Int. Commission on Large Dams CIGB-ICOLD, Vol. 2, Brasilia, Brazil, Q.89-R.21.

Oehy, C. D., De Cesare, G., and Schleiss, A. J. (2010). "Effect of inclined jet screen on turbidity current." J. Hydraul. Res., 48(1), 81-90.

Oehy, C. D., and Schleiss, A. J. (2007). "Control of turbidity currents in reservoirs by solid and permeable obstacles." J. Hydraul. Eng., 10.1061/(ASCE)0733-9429(2007)133:6(637), 637-648.

Potter, D. U., Stevens, M. P., and Meyer, J. L. (1982). "Changes in physical and chemical variables in a new reservoir due to pumped storage operations." J. Am. Water Resour. Assoc., 18(4), 627-633.

U.S. Bureau of Reclamation. (1993). "Aquatic ecology studies of Twin Lakes, Colorado, 1971-86: Effects of a pumped-storage hydroelectric project on a pair of montane lakes." Monograph No. 43, Denver, CO.

World of Maps. (2008). "Online maps and travel information." Map of Switzerland (overview map), 〈http://www.worldofmaps.net/en/europe/ map-switzerland/overview-map-switzerland-online.htm〉 (Sep. 21, 2008). 